\title{
Application of Peanut Shells Composts in Replacement with Peat on Growth Indices and Physical and Chemical Properties of Violet Growth Media (Viola spp) in Outdoor
}

\author{
Jalal Omidi ${ }^{1, ~ *}$, Samaneh Abdolmohammadi ${ }^{1}$, Abdollah Hatamzadeh ${ }^{1}$, Ali Mahboub Khomami ${ }^{2}$ \\ ${ }^{1}$ Department of Horticulture, Faculty of Agriculture, Guilan University, Rasht, Iran \\ ${ }^{2}$ Faculty Member of Soil and Water Research Department, Gilan Agricultural and Natural Resources Research and Education Center, \\ AREEO, Rasht, Iran
}

Email address:

jalalomidi58@yahoo.com (J. Omidi)

${ }^{*}$ Corresponding author

To cite this article:

Jalal Omidi, Samaneh Abdolmohammadi, Abdollah Hatamzadeh, Ali Mahboub Khomami. Application of Peanut Shells Composts in Replacement with Peat on Growth Indices and Physical and Chemical Properties of Violet Growth Media (Viola spp) in Outdoor. Frontiers in Environmental Microbiology. Vol. 3, No. 5, 2017, pp. 68-72. doi: 10.11648/j.fem.20170305.11

Received: November 24, 2017; Accepted: December 4, 2017; Published: December 26, 2017

\begin{abstract}
Peanut Shells as the waste left from peanut planting, which considerable amount of compost can be used as available resources to replace with peat in cultivation of Ornamental plant growth media. So, in this experiment, five treatments in a completely randomized design with three replications were conducted in outdoor in Lahijan ornamental plants Research Station. Treatments were included: 2 peat +1 perlite +0 Shells Peanut composts (control), 1.5 Peat +1 perlite +0.5 Shells peanut compost, 1 Peat +1 perlite +1 Shells Peanut composts, 0.5 Peat +1 perlite +1.5 peanut shells compost, 0 peat + 1 perlite +2 peanut shells compost. In this experiment growth index of violets are included, number of flower, plant height, fresh and dry weight of canopy, root length, root fresh and dry weight, and physical and chemical properties of substrates were measured. The results showed that replacement of Shells Peanut compost has a significant effect on, number of flowers, plant height, Dry weight of canopy, root fresh and dry weight in comparison to control. Increasing levels of Peanut Shells compost caused to reduce in bulk density and an increase in total porosity, Water capacity and air fill porosity.
\end{abstract}

Keywords: Growth Media, Total Porosity, Organic Material, Micro-Organism, Bulk Density

\section{Introduction}

The Genus Viola belongs to the family Violaceae and contains about 500 species (Tamas, 1999). Violets have become the most popular annual for mid-fall to late-spring color in the Southeast. In the past 50 years new violet colors such as shades of pink, rose, and orange have become available. Intensive breeding programs that have selected forunique flower colors, large flower size, greater flower number, and temperature tolerance haveled to many new and exciting cultivars to select from for use in the landscape. Modern violet breeding is largely concentrated in Germany, the United States, and Japan (Derthick et al., 1990). When soil is used as growth media for ornamental plants due to constant problems in the soil quality, this will provide severe and undesirable physical problems. Therefore, breeders are forced to use growth media that are characterized with Soilles culture. Using organic material is costly and difficult to provide for growth media, however, there is an urgent need for materials which replace to peat, from it should be used as a general organic matter, could be used them Successfully as well (Benito et al., 2005). Severe exploitation and overuse of peat may reduce the depth of the deep grasslands (70-160 $\mathrm{cm})$. This not only causes loss of valuable vegetation, but also by providing from adjacent water drainage will affect the vegetation of the area which not utilized. Possibility of rehabilitation of these lands (lands utilized by peat), to its original status or even close to it due to removal of the peat layer even in long term process, is beyond imagination. These factors have led to, worldwide Researchers are 
thinking of low price and good quality growth media. Therefore using of high quality materials with cheaper price instead of peat has been considered (Krumfolz et al., 2000). With the awareness increasing of environmental hazards about waste in addition to disposal or recycle them, and also to reduce the consumption of non-renewable resources such as peat, using more of the bio-solid in agriculture has been recommended. (Bugbee, 2002; Papafotiou et al., 2005). Some studies showed that the peat can be replaced by organic wastes such as municipal wastes, sewage sludge, livestock manure, paper, waste of pruning and fungi beds and other organic waste after composting (Gayasinghe et al., 2010). Composting is an old developed technique which used to reapply organic residue (Anonymous, 1978). Composting means to analysis organic matter by means of microorganism in a warm, damp and aerobic environment (Dalzell et al., 1987). Or biologic analysis of mass organic residue in a controlled condition (Hartmann et al., 1997). Compost by having physical and chemical properties similar to peat could be proper substituted for peat (Sanchez-Monedero et al., 2004). Some of the studies showed that organic residue such as urban residue, sewage ooze, animal fertilizer, paper; pruning residue and fungous bed and any green residue after composting can be substitute peat in growth media (Gayasinghe, et al 2010). (Chen, et al., 1988) Riddling animal fertilizer along with composted of grape residue could be introduce instead of peat in ornamental production. (Baran, et al., 2001) used the grape residue instead of peat to breed Hypoestes plant and they found out that the amount of grape residue compost should be $50 \%$ in the growth media.

According above subject, aim of this research is as follows:

1. Utilize possibility of Shells peanut compost in replacement with peat in growth media without soil.
2. Study the effect of Peanut Shells compost properties of growth media on Violet plant (Viola spp) in outdoor on growth and physical and chemical.

\section{Material and Methods}

To determine the effect of the amount of Shells peanut on growth, physical and chemical properties of growth media on Violet plant, peanut Shells provided from the Stripper factory in Astaneh city. Then peanuts get wet and after adding 1.5 Urea kg per cubic meter Shells to it then poured in Wooden boxes with dimensions $1 \times 1 \times 1 \mathrm{~m}$ which having pores to provide aerobic conditions and microorganism activities to accelerate the fermentation, The aerated done in a chamber where compost was produced. Composting process lasted four months. Peanut shells compost as an alternative bed to peat for breeding violets plants based on a completely randomized design with five treatments and three replications evaluated in Outdoor of Lahijan Ornamental Plants Research Station with geographical specifications $37^{\circ}, 11^{\prime}, 44^{\prime \prime}$ North, $50^{\circ}, 1^{\prime}, 3^{\prime \prime}$ and south. Violets seedling plant (Viola spp) provided from Mr. Ali Keyvani, s greenhouse located in Roudsar. These seeds In terms of height and number of leaves were similar. Peat bought as ready made from Kikila Company in Finland. 1 to $2 \mathrm{~mm}$ Perlite used in this experiment. Basic test growth media for peat - perlite considered and provided in a ratio of $2: 1$. Peanut Shells compost produced after passing through a sieve of $20 \mathrm{~mm}$ width of certain proportions $(0,25,50,75$ and $100 \%$ by volume) instead of peat in growth media 2:1 peat - perlite replaced. It is mentioned that all treatments in $2: 1$ peat and perlite, perlite with constant volume applied and compost of Shells Peanut was replaced by Peat (Table 1).

Table 1. Characteristics of Treatments used in the Experiment.

\begin{tabular}{lll}
\hline Treatment & \% of Compost Peanut Shells & Characteristics \\
\hline 1 & $0 \%$ & 2 peat +1 perlite +0 shells peanut composts (control) \\
2 & $25 \%$ & 1.5 peat +1 perlite +0.5 shells peanut composts \\
3 & $50 \%$ & 1 peat +1 perlite +1 shells peanut composts \\
4 & $75 \%$ & 0.5 peat +1 perlite +1.5 shells peanut composts \\
5 & $100 \%$ & 0 peat +1 perlite +2 shells peanut composts \\
\hline
\end{tabular}

After providing growth media with specific ratios according to experimental design, proceed to the transplanting of violet seedling. Transplanting seedlings were transferred into pots of box with length, width and height of $40 \mathrm{~cm}$. Thus, first after preparing beds, violet transplant seedlings kept out of boxes, and roots were washed with water until it is completely separate from their previous growth media. Then for each pot with a new growth media, four plants were cultivated until five month period of growth to be completed. After ending five month period of violet plant, characters such as flower number, plant height, fresh and dry weight of canopy, root length, root fresh and dry weight and physical and chemical properties of the growth media were measured. To measure the physical properties of the growth media was used Fonteno method (Fonteno, 1996).
To measure total nitrogen in cultivated bed was used Kjeldal method and single device of Kjltak (Goss, 1995). To measure phosphor in the growth media was used (Page et al., 1982) method. Then Phosphor by using of spectrophotometer with the Apel-PD-303UV model at a wavelength of $880 \mathrm{NM}$ was read. Potassium was read by a flame photometer device which called jenway. Fe and $\mathrm{Zn}$ were measured by atomic absorption. To measure organic carbon Walky and Black method was used (Paye et al., 1984) and for measuring $\mathrm{pH}$ and EC on the growth media was used Verdonck and Gabriel (Verdonck and Gabriels, 1992) method. The experimental result of statistical analysis of the data obtained through SAS for 9.1 (statistical programs) and mean comparison was performed by Duncan's multiple range test. 


\section{Results and Discussion}

Analysis of variance indicated significant indices on the number of flowers, plant height, dry weight of the canopy and Root dry weight at a level $1 \%$ and also root fresh weight at level \%5 (Table 2). Regarding to mean comparison application of different levels of Shells peanut compost showed significant effect on number of flower, plant height, dry weight of the canopy, root fresh and dry weight than to the control. Replacing 50\% of the Shells Peanut compost has highest number of flowers (33.33 flower), fresh weight of canopy (35.18 g), dry weight of canopy (8.91 g), root length (11.17 $\mathrm{cm})$, fresh weight of roots $(10.83 \mathrm{~g})$ and dry root weight $(2.37$ g) and replacing $100 \%$ of peanut shells compost was observed with maximum plant height $(21.25 \mathrm{~cm})$ (table 3$)$.

Table 2. Analysis of Variance Indices for Violet Plant Growth.

\begin{tabular}{llllllll}
\hline $\begin{array}{l}\text { Source of } \\
\text { variation }\end{array}$ & $\begin{array}{l}\text { Degrees of } \\
\text { freedom }\end{array}$ & $\begin{array}{l}\text { Number of } \\
\text { flower }\end{array}$ & $\begin{array}{l}\text { Plant } \\
\text { height }\end{array}$ & $\begin{array}{l}\text { Fresh weight of } \\
\text { canopy }\end{array}$ & $\begin{array}{l}\text { Dry weight of } \\
\text { canopy }\end{array}$ & $\begin{array}{l}\text { Root } \\
\text { length }\end{array}$ & $\begin{array}{l}\text { Root fresh } \\
\text { weight }\end{array}$ \\
\hline Treatment & 4 & $71.56^{* *}$ & $17.54^{* *}$ & $135.73 \mathrm{~ns}$ & $8.00^{* *}$ & $\begin{array}{l}\text { Root Dry } \\
\text { weight }\end{array}$ & $2.13 \mathrm{~ns}$ \\
Error & 10 & 3.46 & 1.92 & 56.94 & 0.72 & $1.60^{* *}$ & 1.46 \\
C. V $(\%)$ & & 7.43 & 7.67 & 28.37 & 13.58 & 6.21 \\
\hline
\end{tabular}

**, * and ns were significant at level \%1 respectively, $5 \%$ and were non - significant.

Table 3. Mean Comparison of Growth Indices of Violet Plant Under Different Composting Levels.

\begin{tabular}{|c|c|c|c|c|c|c|c|}
\hline Treatment & $\begin{array}{l}\text { Number of } \\
\text { flower }\end{array}$ & $\begin{array}{l}\text { Plant height } \\
(\mathrm{cm})\end{array}$ & $\begin{array}{l}\text { Fresh weight of } \\
\text { canopy }(\mathrm{g})\end{array}$ & $\begin{array}{l}\text { Dry weight of } \\
\text { canopy (g) }\end{array}$ & $\begin{array}{l}\text { Root length } \\
(\mathrm{cm})\end{array}$ & $\begin{array}{l}\text { Root fresh } \\
\text { weight (g) }\end{array}$ & $\begin{array}{l}\text { Root dry } \\
\text { weight (g) }\end{array}$ \\
\hline 1 & $25.00 \mathrm{~b}$ & $17.41 \mathrm{bc}$ & $30.06 \mathrm{a}$ & $4.75 \mathrm{~b}$ & $10.49 \mathrm{a}$ & $4.36 \mathrm{~b}$ & $0.63 \mathrm{~b}$ \\
\hline 2 & $22.00 \mathrm{~b}$ & $17.31 \mathrm{bc}$ & $26.32 \mathrm{a}$ & $6.61 \mathrm{~b}$ & $9.93 \mathrm{a}$ & $3.72 \mathrm{~b}$ & $0.64 \mathrm{~b}$ \\
\hline 3 & $33.33 \mathrm{a}$ & $19.47 \mathrm{ab}$ & $35.18 \mathrm{a}$ & $8.91 \mathrm{a}$ & $11.17 \mathrm{a}$ & $10.83 \mathrm{a}$ & $2.37 \mathrm{a}$ \\
\hline 4 & $21.00 \mathrm{~b}$ & $14.85 \mathrm{c}$ & $24.32 \mathrm{a}$ & $5.68 \mathrm{~b}$ & $10.25 \mathrm{a}$ & $5.58 \mathrm{ab}$ & $0.94 \mathrm{~b}$ \\
\hline 5 & $24.00 \mathrm{~b}$ & $21.25 \mathrm{a}$ & $17.11 \mathrm{a}$ & $5.30 \mathrm{~b}$ & $8.88 \mathrm{a}$ & $4.15 \mathrm{~b}$ & $0.83 \mathrm{~b}$ \\
\hline
\end{tabular}

Average per column having at least one similar letter according to Duncan's test at $\% 5$, has no significant difference.

[Gayasinghe et al., 2010] used synthetic compounds of manure fertilizers compost as an alternative of peat for breeding ornamental plant of Tagetes which caused to increase plant height, number of flowers per plant, weight of wet and dry canopy, root length, fresh weight and dry root, synthetic compound of manure fertilizer showed 60 and 40 percent increase in treatment, respectively and introduced it instead of expensive peat. with regarding to table (4) The bulk density of growth media by adding peanut shells compost to the control decreased. Maximum bulk density $0.64 \mathrm{gr} / \mathrm{cm}^{3}$ related to bed control and the lowest bulk density $0.32 \mathrm{gr} / \mathrm{cm}^{3}$ by $100 \%$ applicability was observed in peanut shells compost (Gayasinghe et al., 2010) With increasing volumes of manure fertilizer compost in replacing with handy made aggregates, reported a decrease in bulk density. It seems that cellulose tissue of peanuts Shells and particle size of this compost, by developing high porosity caused to decrease the bulk density to the control. The most total porosity value was $72.19 \%$ with $100 \%$ applicability of compost and the lowest total porosity value was $36.43 \%$ was in the control that is related to the impact of the peanut shells compost on bulk density of the growth media. So that by increasing the volume ratio of compost the rate of bulk density of the growth media decreased, subsequently the rate of porosity increased. Water Percentage capacity of growth media was less than of ideal area for plant cultivation. According to (Nappi and Barberis, 1993) the capacity of aqueous in ideal growth media was 55 to 85 percent. With increasing the value of peanut shells compost in growth media, air fill porosity increased. The highest air fill porosity was $53.84 \%$ with $100 \%$ of compost capability the least air fill porosity was $21.65 \%$ in the control. According (Abad et al., 2001) the value of ideal air fill porosity in the growth media for breeding plants was between $20-30 \%$ (Table 4).

Table 4. Effect of Peanut Shells Compost on the Physical Properties of the Growth Media.

\begin{tabular}{|c|c|c|c|c|c|}
\hline Treatment & Peanut shells compost $(\%)$ & Bulk density (gr/cm ${ }^{3)}$ & Total porosity (\%) & Water capacity (\%) & Air fill porosity (\%) \\
\hline 1 & $0 \%$ & 0.64 & 36.43 & 14.78 & 21.65 \\
\hline 2 & $25 \%$ & 0.53 & 40.76 & 14.54 & 26.22 \\
\hline 3 & $50 \%$ & 0.48 & 53.86 & 15.95 & 37.91 \\
\hline 5 & $100 \%$ & 0.32 & 72.19 & 18.35 & 53.84 \\
\hline
\end{tabular}

$\mathrm{pH}$ in the optimal range of growth media was located for breeding of ornamental plants. So that according to (Abad, et al., 2001) $\mathrm{pH}$ for optimum plant growth was determined 5.3 6.5. Most of the EC in growth media by replacing $25 \%$ of the compost was observed for $1.17 \mathrm{ds} / \mathrm{m}$. The amount of nitrogen in growth media by replacing with Shells peanut compost reduce in comparison to control. Most nitrogen observed in control was 2.43 percent. Phosphorus with increasing Shells peanut compost decreased. Most phosphor in control board was $564.33 \mathrm{mg} / \mathrm{kg}$. Potassium increase was observed with increasing of peanut Shells compost replacement levels. Most potassium with $75 \%$ compost application in rate of 637.45 
$\mathrm{mg} / \mathrm{kg}$ was observed. It seems that the absorption rate and material ingredient density of plant tissues depends on different factors such as plant species, temperature and salinity rate in growth media (Grigatti et al., 2007). Amounts of micronutrients (iron and zinc) in growth media by increasing peanut Shells compost level replacement to control increased. Most iron with 75\% application at the rate of $825.14 \mathrm{mg} / \mathrm{kg}$ and the highest zinc was observed with the application of $75 \%$ of the compost at the rate of $14.19 \mathrm{mg} / \mathrm{kg}$. The amount of organic carbon of growth media also by increasing of Peanut Shells compost levels showed a decreasing trend and the highest rate of organic carbon in control board was 28.86 percent (Table 5). Using of organic waste not only will increase the organic matter, but also by increasing micronutrients (such as iron and zinc) to soil leads to improved soil fertility (Nyamangara and Mzezewa, 2001).

Table 5. Chemical Analysis of Growth Media.

\begin{tabular}{|c|c|c|c|c|c|c|c|c|c|}
\hline No & Compost (\%) & $\mathrm{OC}(\%)$ & N (\%) & pH & EC (dS/m) & P (Mg/kg) & K (Mg/kg) & $\mathrm{Fe}(\mathrm{Mg} / \mathrm{kg})$ & $\overline{\mathrm{Zn}(\mathrm{Mg} / \mathrm{kg})}$ \\
\hline 1 & $0 \%$ & 28.86 & 2.43 & 5.84 & 0.98 & 564.33 & 278.88 & 421.68 & 7.68 \\
\hline 2 & $25 \%$ & 25.35 & 2.13 & 5.85 & 1.17 & 482.01 & 418.33 & 709.53 & 9.14 \\
\hline 3 & $50 \%$ & 18.33 & 1.54 & 5.99 & 0.87 & 427.13 & 398.41 & 808.00 & 9.95 \\
\hline 4 & $75 \%$ & 19.11 & 1.61 & 6.19 & 0.84 & 405.79 & 637.45 & 825.14 & 14.19 \\
\hline 5 & $100 \%$ & 10.92 & 0.92 & 6.48 & 0.36 & 177.13 & 338.65 & 794.84 & 9.54 \\
\hline
\end{tabular}

\section{Conclusions}

Replacing of Peanut Shells compost instead of peat Perlite in growth media, led to improved in plant growth indices of Violet in comparing with control, all growth indices measured, using $50 \%$ of the Peanut shells compost had the greatest effect. It seems that Peanut Shells cellulose tissue and size of compost particle, creating high porosity caused to decrease in bulk density and then caused by increasing of total porosity which these would improved growth indices in comparing with control. Considering that the horticulture industry looking for an alternative to the expensive organic material to be used in growth media. The results showed that providing compost from peanut Shells waste is an appropriate method and in accordance with environmental standards, and recommended that peanut shells compost as a recycled material is suitable in growth media. However, It seems necessary to study further on peanut shells compost processing to achieve the best compost particle size for better activity of microorganisms in plant growth media.

\section{References}

[1] Abad, M., P. Noguera and S. Bures. 2001, National inventory of organic wastes for use as growing media for ornamental potted plant production: case study in Spain. Bioresource Technology. 77:197-200.

[2] Anonymous. 1978, Soil Management: organic Recycling in Asia. FAO Soil Bulletin, No. 36.

[3] Baran, A., G. Gayci, C. Kutuk and R. Hartmann. 2001, Composted grape mare as growing medium for Hypostases (Hypostases phyllostagya). Booresource Technology. 78: 103106.

[4] Benito, M., Masaguer, A., De Antonio, R., and. Moliner, A. 2005, Use of pruning waste compost as a component in soilless growing media. Bioresource Technology. 96:597-603.

[5] Bugbee, J. G. 2002, Growth of ornamental plants in container media amended with biosolids compost. Composition Sciense and Utilizatio. 10: 92-98.

[6] Chen, Y., Y. Inbar and Y. Harda. 1988. Composted agricultural wastes as potting media for ornamental plants. Soil Science. 145 (4): 298-303.

[7] Dalzell, H. W., Biddlestone, A. j., Gray, K. R., and Thurairrajan, K. 1987, Soil Management, Compost Production and Use in Tropical and Subtropical Environments. FAO Soil Bulletin, No. 56.

[8] Derthick, S., W. H. Carlson, and L. Ewart. 1990, Producing violets for profit. Mich. State Univ. Coop. Ext. Serv. Bull.

[9] Fonteno, W. C. 1996, Growing media: Types and Physical/Chemical Properties. In D. W. Reed (Ed) Water, Media, and Nutrition of Greenhouse Crops. Ball Publications, Batavia, IL. pp. 93-122.

[10] Gayasinghe. G. Y., Liyana, I., Arachchi, D., and Tokashiki, Y. 2010, Evaluation of containerized substrates developed from cattle manure compost and synthetic aggregates for ornamental plant production as a peat alternative. Resources Conservation and Recycling. 54: 1412-1418.

[11] Goos, R. J., 1995, A laboratory exercise to demonstrate nitrogen mineralization and immobilization, J. Nat. Resour. Life Sciense Education. 24: 68-70.

[12] Grigatti, M., Giorgoni, M. E., Cavani, L., and Ciavatta, C. 2007 , Vactor analysis in the study of the nutritional status of philodendron cultivated in compost-based media. Scientia Horticulturae. 112: 448-455.

[13] Hartmann, H. T., Kester, D. E., Davies, F. T., and Geneve, R. L. 1997, Plant propagation Principles and practices. $6^{\text {th }}$ Prentice, Hall, Inc, USA. 710 pp.

[14] Krumfolz, L. A., S. B. Wilsonand, and P. J. Stoffella. 2000, Use of compost as amedia amendment for containerized production of perennial cat whishkers. SNA Research Conference. 45: 69-72.

[15] Nappi. P and R. Barberis. 1993, Compost as growing medium: chemical, physical and biological aspects. Acta Horticulturae. 342: $249-256$

[16] Nyamangara, J., and Mzezewa, J. 2001, Effect of long-term application of sewage sludge to a grazed pasture on organic carbon and nutrients if clay soil in Zimbabwe. Nutrion Cycling Agroecosyst. 59: 13-18. 
[17] Page, A. L., Miller, R. H., and Keeney, D. R. 1982, Methods of soill Analysis, Part 2, Chemical and microbiological properties. American society of Agronomy, Inc. Soil Science of America, Inc. Madison, Wisconsin, USA.

[18] Papafotiou, M., M. Phsyhalou, G. Kargas, I. Chatzipavlidis and J. Chronopoulos. 2005, Olive-maill waste compost as growth medium component for the production of poinsettia. Horticultural Sciences. 102:167-175.

[19] Paye, A. L., Miller, R. H., and Keeny, D. R. 1984, Method of soil analysis. Part II. SSSA Inc.

[20] Sanchez-Monedero, M., A. Roig, J. Cegarra, M. P. Bernal, P.
Noguera and M. Abad. 2004, Composts as media constituents for vegetable transplant production. Compost Sciense Utilization. 12:161-168.

[21] Tamas, M. 1999, Botanica farmaceutica. Vol III. SistematicaCormobionta, Ed. Medicala Universitara "Iuliu Hatieganu”, Cluj-Napoca, p. 137-138.

[22] Verdonck, O and R. Gabriels. 1992, I. Reference method for the determination of physical properties of plant substrates. II. Reference method for the determination of chemical properties of plant substrates. Acta Horticulturae. 302:169179. 